Sanctified and Chicken-Fried 


\section{SANCTIFIED AND}

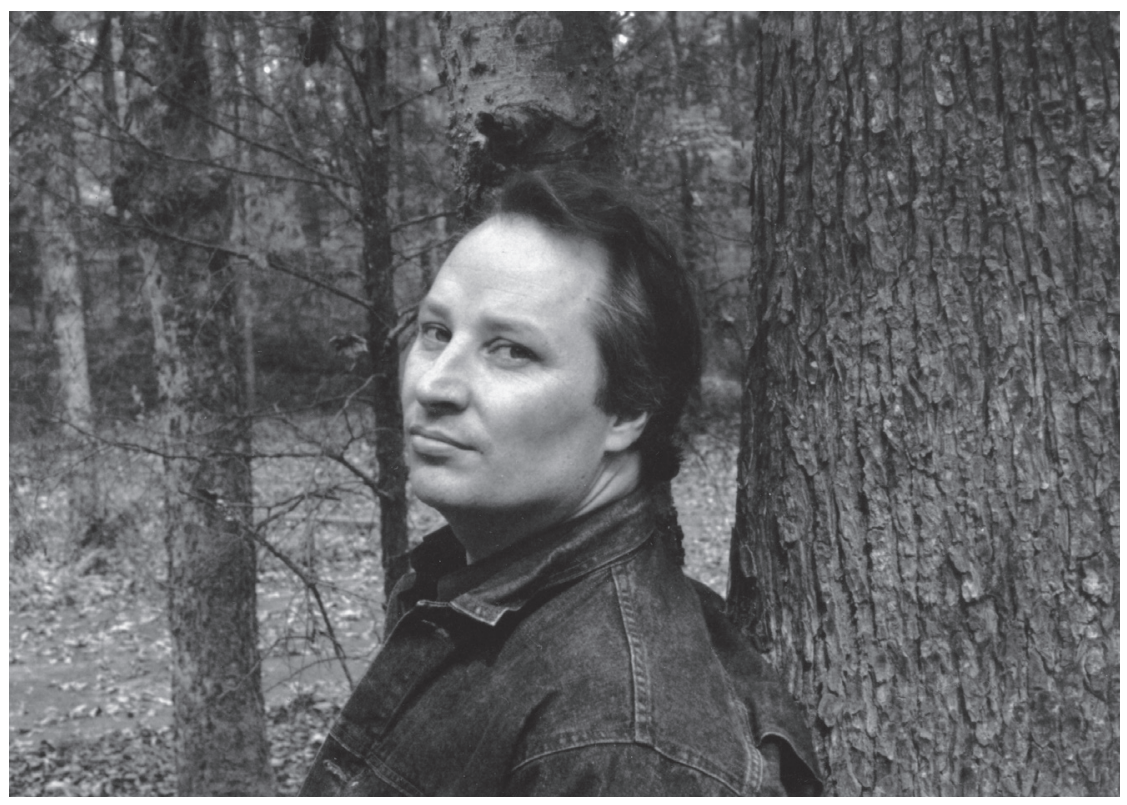

SOUTHWESTERN WRITERS COLLECTION SERIES

The Wittliff Collections at Texas State University-San Marcos

Steven L. Davis, Editor 


\section{CHICKEN-FRIED}

The Portable Lansdale

By JOE R. LANSDALE

$\checkmark$ University of Texas Press, Austin 
The Southwestern Writers Collection Series originates from the Wittliff Collections, a repository of literature, film, music, and southwestern and Mexican photography established at Texas State University-San Marcos.

Copyright (C) 2009 by Joe R. Lansdale

Foreword ( 2009 by the University of Texas Press

All rights reserved

Printed in the United States of America

First edition, 2009

Requests for permission to reproduce material from this work should be sent to:

Permissions

University of Texas Press

P.O. Box 7819

Austin, TX 78713-7819

www.utexas.edu/utpress/about/bpermission.html

$\infty$ The paper used in this book meets the minimum requirements of ANSI/NISO Z39.48-1992 (R1997) (Permanence of Paper).

Library of Congress Cataloging-in-Publication Data

Lansdale, Joe R., 1951-

Sanctified and chicken-fried : the portable Lansdale / by Joe R. Lansdale.

p. cm. - (The Southwestern writers collection series)

An anthology of short stories, excerpts from the novels The magic wagon and A fine dark line, and previously unpublished tales.

ISBN 978-0-292-71941-5 (cl.: alk. paper)

I. Title. II. Title: Portable Lansdale.

PS3562.A557S26 2009

$813 \cdot .54-\mathrm{dc} 22$

2008049636 